\title{
ANALISIS KUALITAS AIR DAN KUALITAS LINGKUNGAN UNTUK BUDIDAYA IKAN DI DANAU LAIMADAT, NUSA TENGGARA TIMUR
}

\author{
ANALYSIS OF WATER QUALITY AND ENVIRONMENTAL QUALITY FOR \\ AQUACULTURE IN LAIMADAT LAKE, EAST NUSA TENGGARA
}

\author{
Obed Lepa Saba Kulla ${ }^{1,2}$, Ernik Yuliana ${ }^{2 *}$, Eddy Supriyono ${ }^{3}$ \\ ${ }^{\text {I}}$ SMK Negeri 1 Mamboro, Sumba Tengah, Nusa Tenggara Timur \\ ${ }^{2}$ Program Magister Manajemen Perikanan, Program Pascasarjana, Universitas Terbuka, Jalan Cabe \\ Raya, Pondok Cabe, Pamulang, Tangerang Selatan, Banten 15418 \\ ${ }^{3}$ Departemen Budidaya Perairan, Fakultas Perikanan dan Ilmu Kelautan, IPB University, Jl. Raya \\ Dramaga, Babakan, Kec. Dramaga, Bogor, Jawa Barat 16680
}

Teregistrasi I tanggal: 23 Agustus 2020; Diterima setelah perbaikan tanggal: 21 September 2020; Disetujui terbit tanggal: 21 September 2020

\begin{abstract}
ABSTRAK
Danau Laimadat merupakan danau terbesar di Kabupaten Sumba Tengah, Nusa Tenggara Timur, dan menjadi lokasi utama budidaya ikan air tawar. Kualitas air dalam budidaya ikan memegang peran penting dan membutuhkan monitoring. Tujuan penelitian adalah menganalisis kesesuaian kualitas air dan kualitas lingkungan Danau Laimadat untuk budidaya ikan air tawar. Waktu penelitian adalah Januari-Mei 2018 berlokasi di Danau Laimadat, Nusa Tenggara Timur. Metode penelitian menggunakan metode survei. Pengumpulan data dilakukan dengan cara observasi dan pengukuran parameter kualitas air di lapangan. Pengambilan data dilakukan pada empat stasiun pengamatan. Analisis data dilakukan secara deskriptif dengan membandingkan kualitas air Danau Laimadat dengan Standar Baku Mutu perairan untuk budidaya ikan air tawar (PP No. 82 Tahun 2001). Hasil penelitian menunjukkan bahwa kualitas air Danau Laimadat sesuai dengan standar baku mutu untuk parameter suhu, $\mathrm{pH}$, dan oksigen terlarut. Parameter kedalaman dan kecerahan air tidak terdapat pada baku mutu, namun kedalaman dan kecerahan sesuai persyaratan budidaya ikan di perairan tawar. Secara visual, tidak terjadi pencemaran pada perairan Danau Laimadat. Dengan demikian, Danau Laimadat layak dijadikan lokasi budidaya ikan air tawar.
\end{abstract}

Kata kunci: Danau Laimadat, perikanan tawar, kualitas air, lingkungan, Sumba Tengah

\begin{abstract}
Laimadat Lake is the largest lake in Central Sumba Regency, East Nusa Tenggara, and is the main location for freshwater fish farming. Water quality in fish farming is an important role, and must always be monitored. The aims of this study were to analyze the suitability of the water quality and environmental quality of Laimadat Lake for freshwater fish aquaculture. The research time was January - May 2018. The research method used the survey method. The data was collected by observing and measuring water quality parameters in the field. Data collection was carried out on four observation stations. Data analysis was carried out descriptively by comparing the water quality of Lake Laimadat with the standard water quality standards for freshwater aquaculture (PP No. 82 of 2001). The results indicated that the water quality of Lake Laimadat was in accordance with the quality standards for temperature, $\mathrm{pH}$, and dissolved
\end{abstract}

Korespondensi penulis:

*Email: ernik@ecampus.ut.ac.id

DOI: http://dx.doi.org/10.15578/plgc.v1i3.9290 
oxygen parameters. The parameters of water depth and brightness are not recorded in the quality standard, but the depth and brightness are according to the requirements for fish farming in freshwater. Visually, there is no pollution in the waters of Lake Laimadat. Thus, Lake Laimadat is suitable as a location for freshwater fish cultivation.

Keywords: Central Sumba, environment, freshwater fish, Laimadat Lake, water quality

\section{PENDAHULUAN}

Indonesia merupakan negara kepulauan yang memiliki sumber daya perikanan sangat besar. Sumber daya perikanan tersebut, jika dikembangkan dengan baik, dapat memberikan manfaat yang maksimum secara berkelanjutan untuk kemakmuran masyarakat Indonesia. Undang-Undang Republik Indonesia Nomor 45 Tahun 2009 Pasal 6 Ayat 1 menegaskan bahwa pengelolaan perikanan ditujukan untuk tercapainya masyarakat yang sejahtera dan makmur, serta terjaminnya kelestarian sumber daya ikan (SDI). Saat ini luas perairan umum Indonesia mencapai 54-55 juta ha (Investor Daily, 2014; Yunita \& Rachman, 2016), terdiri atas 12 juta ha perairan sungai dan paparan banjirnya; 39 juta ha perairan rawa; 2 juta ha perairan danau dan badan air lainnya. Perairan umum Indonesia kaya akan biota, tercatat sekitar 1.200 jenis ikan, 200 jenis udang dan kepiting, 315 jenis moluska, 200 jenis amfibia, dan 100 jenis reptilia (Investor Daily, 2014). Kabupaten Sumba Tengah merupakan salah satu daerah yang memiliki perairan umum seperti danau tadah hujan, sungai, embung, dan cekdam. Ketika musim hujan, potensi perikanan air tawar (betok, gabus, mujair, dan lele lokal) sangat melimpah sehingga menjadi salah satu penghasilan masyarakat Sumba Tengah di musim hujan.

Melihat besarnya potensi perikanan air tawar di Kabupaten Sumba Tengah, pemerintah telah berupaya secara nyata mendukung pemberdayaan masyarakat dengan peningkatan kesejahteraan. Program-program peningkatan kesejahteraan dilakukan melalui peningkatan kemampuan nelayan serta penguatan lembaga pendukungnya yaitu pengamanan ketahanan pangan, peningkatan akses nelayan kepada sumber daya produktif seperti teknologi, informasi pemasaran, pengolahan dan permodalan, perbaikan iklim usaha dalam meningkatan verifikasi usaha dan memperluas kesempatan berusaha. Peningkatan kemampuan manajemen dan kompetensi kewirausahaan di kalangan pelaku usaha bidang perikanan mendorong peningkatan produk perikanan untuk meningkatkan daya saing dan nilai tambah, peningkatan efisiensi sistem distribusi, koleksi, dan jaringan pemasaran produk untuk perluasan pemasaran, dan peningkatan pemanfaatan sumber daya perikanan untuk mendukung pertumbuhan ekonomi dengan tetap menjaga kelestarian sumber daya alam (SDA) dan lingkungan hidup.

Arah pembangunan di Kabupaten Sumba Tengah masih terkonsentrasi di daratan dan bidang lainnya sehingga di bidang perikanan khususnya di perairan umum masih belum tersentuh, meskipun potensi perikanan sangat besar. Pada tahun 1980 potensi perikanan air tawar sangat tinggi, namun beberapa tahun terakhir mengalami penurunan yang diakibatkan beberapa danau mengalami pendangkalan dan kekeringan. Pengembangan budidaya perikanan air tawar di perairan umum seharusnya menerapkan beberapa asepek, yaitu: optimalisasi SDA, menjaga kelestarian lingkungan, peningkatan pendapatan berkelanjutan (Panggabean et al., 2016). Pendekatan pembangunan sebaiknya berorientasi kepada pendekatan 
pembangunan berkelanjutan, holistik, dan berbasis pada masyarakat (Dahuri, 2003). Tanpa filosofi berkelanjutan, maka pembangunan tidak akan memakmurkan kehidupan.

Pengembangan investasi di sektor budidaya perikanan diharapkan dapat memacu pertumbuhan ekonomi, meningkatkan kesempatan kerja dan pendapatan, serta pengembangan wilayah pedesaan. Berkembangnya suatu wilayah sangat tergantung dari potensi dan kemampuan sumber dayanya seperti fasilitas infrastruktur, pendanaan, teknologi, sumber daya manusia (SDM) dan sistem tata niaga komoditas agribisnis/agroindustri di wilayah tersebut. Selain itu, penciptaan iklim usaha yang kondusif bagi pengembangan investasi di bidang budidaya sangat diharapkan bagi pengembang sektor perikanan berkelanjutan.

Kualitas air adalah bagian penting dalam pengembangan budidaya ikan,

\section{BAHAN DAN METODE}

\section{Waktu dan Tempat}

Lokasi penelitian adalah Danau Laimadat, Kabupaten Sumba Tengah, Provinsi Nusa Tenggara Timur (Gambar 1). Pengambilan sampel air dilakukan pada bulan Januari - Mei 2018. Pengkajian kualitas perairan dilakukan dengan tujuan untuk melihat karakteristik perairan Danau Laimadat dan menentukan kondisi perairan yang terkait dengan kelayakan atau kesesuaian habitat bagi perikanan untuk pengembangan budidaya ikan air tawar.

\section{Alat dan bahan}

Alat dan bahan yang digunakan untuk menganalisis kondisi parameter kualitas air adalah kamera untuk pengambilan gambar danau, global positioning system (GPS) sebagai alat penentu posisi pengambilan contoh dan posisi kisaran danau, alat-alat pengukuran kualitas air seperti alat pengukur oksigen sehingga analisis kualitas air sangat diperlukan (Panggabean et al., 2016; Zamzami et al., 2019;). Pulford et al. (2017) menjelaskan bahwa pemantauan kualitas air danau merupakan kegiatan yang penting karena danau merupakan penghasil ikan air tawar dan sarana rekreasi. Monitoring kualitas air danau juga penting sebagai dasar dalam pengambilan kebijakan pengelolaan sumber daya air (Lihawa \& Mahmud, 2017). Kelayakan suatu lokasi perairan umum merupakan hasil kesesuaian di antara persyaratan hidup dan berkembangnya suatu komoditas budidaya perikanan terhadap lingkungan fisik perairan umum. Tujuan penelitian adalah menganalisis kualitas air dan kualitas lingkungan untuk kesesuaiannya dengan budidaya ikan di Danau Laimadat, Kabupaten Sumba Tengah, Nusa Tenggara Timur.

terlarut (DO Meter 5510), $\mathrm{pH}$ Meter 212, Secchi disk, fishfinder 160C, termometer, serta alat-alat tulis untuk mencatat data. Bahan yang digunakan adalah peta lokasi Danau Laimadat dan beberapa dokumen terkait.

\section{Pengumpulan Data}

Pengumpulan data kualitas air mengacu pada prosedur pada SNI 6989.57:2008 tentang Metode Pengambilan Sampel Air Permukaan. Jenis data yang dipergunakan dalam penelitian ini adalah data primer. Pengumpulan data dilakukan dengan observasi dan survei di lapangan, yang dilakukan di empat stasiun pengamatan. Stasiun I terletak pada bagian utara danau tepatnya di belakang GKS Jemaat Mambitul, Stasiun II pada sebelah barat danau tepatnya di bawah perkampungan Radak Galukalebung, Stasiun III di sebelah timur tepatnya di belakang SMTK Waibakul dan sebelah selatan di daerah padang, Stasiun IV di bagian utara danau. 


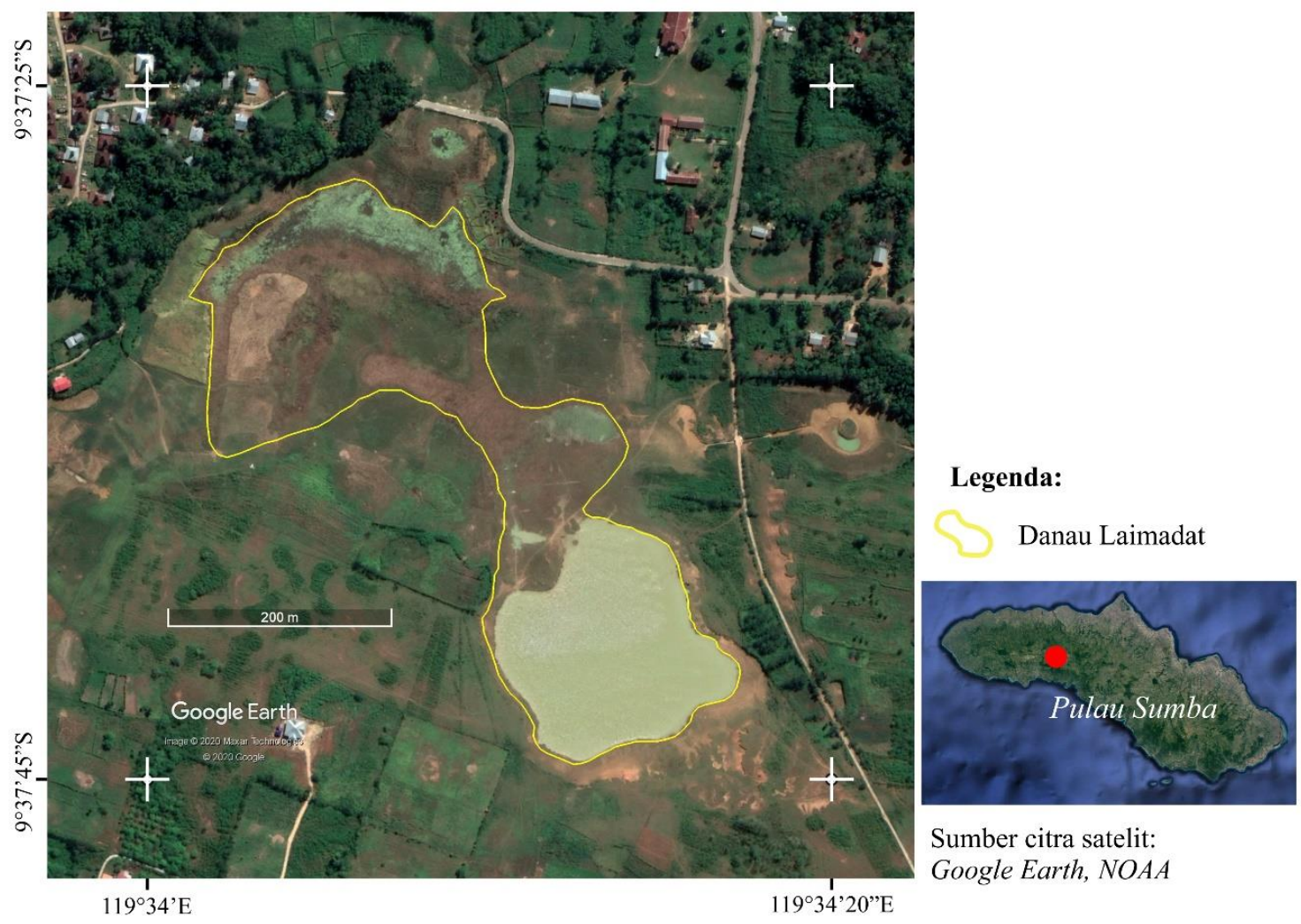

Gambar 1. Lokasi penelitian, Danau Laimadat (Sumber: Google Earth) Figure 1. Study site, Laimadat Lake (Source: Google Earth)

Observasi lapangan dilakukan dengan meninjau langsung kondisi lokasi di lapangan dengan melakukan pengambilan contoh (sampling) pada beberapa parameter kualitas air, tanaman air, dan ikan.

Nilai kecerahan diperoleh dengan menggunakan rumus:

$$
\text { Kecerahan }(\mathrm{m})=(\mathrm{d} 1+\mathrm{d} 2) / 2
$$

Keterangan:

$\mathrm{d} 1=$ skala saat bagian Secchi disk berwarna putih tidak tampak lagi (m)

$\mathrm{d} 2=$ skala saat bagian Secchi disk berwarna hitam pertama kali tampak (m)

\section{Analisis Data}

Analisis data dilakukan secara deskriptif dalam bentuk tabel, grafik, dan uraian, dan hasil analisis data disesuaikan dengan baku mutu perairan untuk budidaya ikan.

\section{HASIL DAN BAHASAN HASIL}

Kualitas Air

Danau Laimadat memiliki luas +10 ha berada pada $09^{\circ} 37^{\prime} 44,76^{\prime \prime}$ LS dan $119^{\circ} 34^{\prime} 16,32 "$ BT berfungsi sebagai daerah resapan air dan merupakan danau besar di Kabupaten Sumba Tengah (Gambar 1). Sumber utama air danau umumnya berasal dari curah hujan (tadah hujan). Debit air Danau Laimadat cukup tinggi dimanfaatkan oleh masyarakat di sekitar danau untuk keperluan pertanian, perikanan, peternakan, dan untuk keperluan mandi, cuci, kakus (MCK). Bahkan dengan kualitas air yang masih sangat baik, air danau dimanfaatkan sebagai sumber air bersih bagi masyarakat sekitar. Namun, pada saat kemarau, kadang-kadang danau ini mengalami kekeringan di sebagian wilayahnya (Gambar 1). 
Hasil pengukuran kualitas air pada empat stasiun pengamatan pada bulan Februari disajikan pada Tabel 1, sedangkan pada bulan April disajikan pada Tabel 2.

\section{Kesesuaian Kualitas Air dengan Baku Mutu}

Tingkat produktivitas perairan antara lain ditentukan oleh faktor lingkungan, terutama kesesuaian kualitas air (Ningsih et al., 2016). Suhu, pH, dan oksigen terlarut berperan penting bagi kehidupan dan perkembangan biota perairan danau, terutama $\mathrm{pH}$ dan oksigen terlarut (Ningsih et al., 2016). Suhu optimum untuk budidaya ikan adalah suhu normal dengan deviasi $\pm 3{ }^{\circ} \mathrm{C}$ yang mengacu pada Peraturan Pemerintah Republik Indonesia (PP) Nomor 82 Tahun 2001 tentang Pengelolaan Kualitas Air dan Pengendalian Pencemaran Air.

Derajat keasaman $(\mathrm{pH})$ sangat berpengaruh terhadap pertumbuhan dan kelangsungan hidup ikan, pada $\mathrm{pH}$ rendah (asam, $\mathrm{pH}<5$ ) dan $\mathrm{pH}$ tinggi (basa, $\mathrm{pH}>11$ ) dapat menimbulkan kematian ikan dan tidak terjadi reproduksi. Nilai $\mathrm{pH}$ air Danau Laimadat berkisar antara 6,2-
7,8. Nilai $\mathrm{pH}$ terendah pada Stasiun II dan pH tertinggi pada Stasiun IV. Derajat keasaman yang ideal bagi kehidupan biota air tawar adalah $6,8-8,5$. Nilai $\mathrm{pH}$ yang sangat rendah menyebabkan kelarutan logam-logam dalam air semakin besar, yang bersifat toksik bagi organisme air.

Oksigen terlarut (DO) terendah sebesar 7,40 ppm tercatat di Stasiun IV dan yang tertinggi pada titik pengamatan Stasiun I sebesar 7,52 ppm. Oksigen berasal dari proses difusi udara dan fotosintesis serta dipengaruhi oleh suhu. Peningkatan suhu menyebabkan penurunan oksigen terlarut, dan begitu juga sebaliknya (Nybakken, 1988).

Kedalaman perairan sangat penting bagi kelayakan budidaya perikanan, dengan kedalaman perairan yang optimum sedalam 4-5 meter. Hasil pengukuran kedalaman air danau berkisar antara 2,54,5 m. Sumber air utama dari Danau Laimadat ini berasal dari hujan, semakin besar curah hujan air danau semakin meningkat debitnya dan pada saat penelitian berlangsung air danau masih dalam kondisi yang banyak.

Perbandingan hasil pengukuran di lapangan dengan standar baku mutu untuk

Tabel 1. Parameter kualitas air Danau Laimadat Februari 2018

Table 1. Water quality parameter of Laimadat Lake on Februari 2018

\begin{tabular}{lccccc}
\hline Parameter Kualitas Air & \multicolumn{3}{c}{ Stasiun } & \multirow{2}{*}{ Rata-rata } \\
\cline { 2 - 5 } & I & II & III & IV & \\
\hline Kedalaman (m) & $4-5$ & $3-4$ & $4-6$ & $4-6$ & $4-6$ \\
Kecerahan $(\mathrm{m})$ & $2-4$ & $2-3$ & $2-4$ & $2-4$ & $2-4$ \\
Suhu $\left({ }^{\circ} \mathrm{C}\right)$ & 29 & 28 & 30 & 30 & 29,25 \\
pH & 7 & 6,2 & 7,5 & 7,8 & 7,13 \\
Oksigen terlarut $(\mathrm{ppm})$ & 7,51 & 7,52 & 7,50 & 7,50 & 7,50 \\
\hline
\end{tabular}

Tabel 2. Parameter kualitas air Danau Laimadat April 2018

Table 2. Water quality parameter of Laimadat Lake on April 2018

\begin{tabular}{lccccc}
\hline Parameter Kualitas Air & \multicolumn{3}{c}{ Stasiun } & \multirow{2}{*}{ Rata-rata } \\
\cline { 2 - 5 } & I & II & III & IV & \\
\hline Kedalaman (m) & $3-4$ & $2.5-4$ & $4-5$ & $4-5$ & $4-5$ \\
Kecerahan $(\mathrm{m})$ & $2-4$ & $2-3$ & $2-4$ & $2-4$ & $2-4$ \\
Suhu $\left({ }^{\circ} \mathrm{C}\right)$ & 29 & 29 & 31 & 31 & 30 \\
$\mathrm{pH}$ & 7,5 & 7,2 & 7,2 & 7,5 & 7,35 \\
Oksigen terlarut $(\mathrm{ppm})$ & 7,52 & 7,50 & 7,41 & 7,40 & 7,46 \\
\hline
\end{tabular}


kegiatan ikan air tawar (Kelas II) menurut PP Nomor 82 Tahun 2001 dan kondisi perairan yang baik untuk menunjang kegiatan budidaya ikan air tawar berdasarkan literatur dapat dilihat pada Tabel 3.

Pada landscape Danau Laimadat terdapat tanam-tanaman berumur panjang yang terutama berda di bagian barat danau seperti pohon mahoni dan jati putih. Kondisi ini meningkatkan daya resapan air wilayah sehingga air Danau Laimadat tidak pernah kering sepanjang tahun. Masyarakat yang berada di sekitar Danau Laimadat juga banyak yang memanfaatkan lahan di sekitar danau untuk menanam tanaman sayuran dan holtikultura pada saat musim kemarau.

\section{Komoditas Ikan}

Selama ini, masyarakat lokal di sekitar Danau Laimadat melakukan penangkapan ikan sebagai mata pencaharian. Masyarakat belum melakukan budidaya perikanan. Hasil tangkapan ikan adalah ikan gabus, betok Anakalang, nila, mujair, sepat, mas/karper, lele, wader, dan udang air tawar. Komunitas ikan air tawar Danau Laimadat Kabupaten Sumba Tengah didominasi oleh ikan betok Anakalang, ikan gabus dan ikan lele lokal, sedangkan ikan nila dan mas merupakan tebaran dari Dinas Kelautan dan Perikanan Kabupaten Sumba Tengah. Setiap hari masyarakat yang berada di sekitar Danau Laimadat melakukan penangkapan ikan dengan menggunakan alat tangkap tradisional.
Keberadaan ikan di Danau Laimadat ini sangat berpotensi untuk mendukung pengembangan budidaya ikan air tawar.

Tanaman air yang ditemukan saat penelitian antara lain enceng gondok, teratai, dan padian. Keberadaan tanaman enceng gondok ini sebagai pembersih polutan dan tanaman teratai yang hidup di permukaan air yang tenang memiliki manfaat sebagai tempat meletakkan telur ikan pada danau.

\section{BAHASAN}

Kualitas air adalah parameter yang harus selalu dipantau dalam budidaya ikan air tawar (Andria \& Rahmaningsih, 2018; Zamzami et al., 2019). Kondisi kualitasi ari di Danau Laimadat secara umum baik, dengan perincian sebagai berikut. Kecerahan di Danau Laimadat berada dalam kondisi alami karena perairan dengan tingkat kecerahan $2 \mathrm{~m}$ sangat baik untuk lokasi budidaya ikan. Berdasarkan kriteria kelayakan lokasi, nilai kecerahan berada dalam kategori sangat layak dan layak untuk komoditas budidaya ikan dengan luasan +10 ha. Kedalaman air Danau Laimadat berkisar antara 2,5-5 m, hal ini sesuai dengan nilai PP No. 82 Tahun 2001yang layak untuk kegiatan budidaya ikan.

Suhu pada lokasi penelitian dari semua stasiun menunjukkan bahwa keadaan suhu air layak dan memenuhi syarat untuk dilakukan kegiatan pengembangan budidaya ikan. Menurut PP No 82 Tahun 2001 kisaran suhu yang

Tabel 3. Perbandingan nilai kualitas air menurut standar baku mutu PP No 82 Tahun 2001

Table 3. Comparison of water quality values according to quality standards in Government Regulation No. 82 of 2001

\begin{tabular}{|c|c|c|c|}
\hline Parameter/Satuan & $\begin{array}{c}\text { Hasil } \\
\text { Pengukuran }\end{array}$ & $\begin{array}{c}\text { Standar Baku Mutu untuk kegiatan } \\
\text { budidaya ikan air tawar (Kelas II) } \\
\text { PP No. } 82 \text { Tahun } 2001\end{array}$ & Keterangan \\
\hline Kedalaman (m) & $4-6$ & 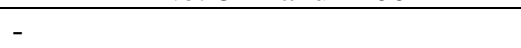 & Sesuai \\
\hline Kecerahan (m) & $2-4$ & - & Sesuai \\
\hline Suhu $\left({ }^{\circ} \mathrm{C}\right)$ & $29,63^{\circ} \mathrm{C}$ & Deviasi 3 dari suhu normal & Sesuai \\
\hline $\mathrm{pH}$ & 7,24 & $6-9$ & Sesuai \\
\hline Oksigen terlarut (ppm) & 7,48 & 4 & Sesuai \\
\hline
\end{tabular}


sesuai untuk kegiatan budidaya air tawar (Kelas II) adalah deviasi 3, sedangkan toleransi perairan yang baik untuk menunjang pertumbuhan optimal dari beberapa ikan budidaya air tawar seperti ikan mas dan ikan nila adalah $28^{\circ} \mathrm{C}$. Suhu berpengaruh secara langsung pada laju proses fotosintesis dan proses fisiologi hewan (derajat metabolisme proses reproduksi) yang selanjutnya berpengaruh terhadap cara makan dan pertumbuhannya (Andria \& Rahmaningsih, 2018). Suhu air dipengaruhi oleh kecerahan dan kedalaman. Air yang dangkal dan daya tembus cahaya matahari dapat meningkatkan suhu perairan. Kecerahan air tergantung pada warna dan kekeruhan. Nilai kecerahan sangat dipengaruhi oleh keadaan cuaca, waktu pengukuran. Kedalaman mempengaruhi jumlah/debit air dalam suatu luasan perairan yang sama. Perairan danau Laimadat merupakan danau yang dapat ditembusi cahaya matahari hingga ke dasar danau sehingga proses fotosintesis tumbuhan air dapat berlangsung dengan baik.

Derajat keasaman $(\mathrm{pH})$ sangat berpengaruh terhadap pertumbuhan dan kelangsungan hidup ikan. Nilai $\mathrm{pH}$ yang optimal untuk budidaya ikan adalah 6,5 9,0 dan berdasarkan standar baku mutu air PP No. 82 Tahun 2001 (kelas II), pH yang baik untuk kegiatan budidaya ikan air tawar berkisar antara $6-9$. Hal ini menunjukkan bahwa $\mathrm{pH}$ perairan danau Laimadat Kabupaten Sumba Tengah berada dalam batas alami dan masih layak untuk dilakukan kegiatan usaha budidaya ikan air tawar karena berada pada kisaran $6,2-7,8$.

Sebagian besar biota akuatik sensitif terhadap perubahan $\mathrm{pH}$ dan menyukai nilai $\mathrm{pH}$ antara $7-8,5$. Nilai $\mathrm{pH}$ sangat mempengaruhi proses biokimiawi perairan, misalnya proses nitrifikasi akan berakhir jika $\mathrm{pH}$ rendah. $\mathrm{pH}$ perairan Danau Laimadat yang berkisar antara 6,2 7,8 ini berarti keanekaragaman plankton dan benthos meningkat dan produktivitas tidak mengalami perubahan.
Oksigen terlarut merupakan parameter yang paling kritis dalam budidaya ikan. Oksigen berasal dari proses difusi udara dan fotosintesis, serta dipengaruhi oleh suhu. Peningkatan suhu menyebabkan penurunan oksigen begitu juga sebaliknya (Nybakken, 1988). Hasil penelitian menunjukkan bahwa nilai DO berada pada kisaran $7,40-7,52 \mathrm{mg} / \mathrm{l}$. Nilai tersebut dikategorikan baik bagi pengembangan budidaya ikan air tawar karena masih berada di atas ambang batas mutu kualitas air (Kelas II) menurut PP. No 82 Tahun 2001 yaitu > 4mg/l. Hasil ini menunjukkan bahwa limbah domestik dari masyarakat sekitar Danau Laimadat masih dalam tingkat yang rendah. Penelitian Muthifah et al. (2018) mendapatkan bahwa rendahnya nilai DO di perairan danau pada umumnya disebabkan oleh limbah domestik. Sumber oksigen terlarut (DO) dalam air berasal dari difusi oksigen yang terdapat di atmosfer dalam kondisi perairan diam (faktor arus sedikit), difusi karena adanya turbulensi akibat adanya arus atau aliran air melalui air hujan serta aktivitas fotosintesis tumbuhan air dan fitoplankton.

Hasil pengukuran kualitas air untuk semua stasiun pengamatan menunjukkan bahwa perairan Danau Laimadat berada dalam kategori layak untuk pengembangan budidaya ikan air tawar. Analisis terhadap kesesuaian perairan Danau Laimadat memperlihatkan tingkat kesesuaian dengan kategori tinggi sehingga dapat dikatakan bahwa perairan Danau Laimadat layak dan sesuai serta memiliki prospek untuk dikembangkan budidaya ikan air tawar karena memiliki lahan yang sangat berpotensi untuk dimanfaatkan.

Terkait dengan dampak lingkungan, daya dukung lingkungan merujuk pada tingkat maksimum kegiatan yang akan mengakibatkan penurunan sumberdaya secara fisik atau kerusakan habitat alami. Pada perairan Danau Laimadat belum ada indikasi pencemaran dan bersifat alamiah, sehingga dari segi daya dukung perairan 
sesuai untuk dikembangkan kegiatan budidaya perikanan. Dengan diketahuinya daya dukung dan pemanfaatan perairan, budidaya perikanan di Danau Laimadat dapat dikembangkan secara berkelanjutan. Beberapa faktor yang harus diperhatikan dalam pengembangan lahan untuk budidaya perikanan yaitu sumber air (debit air dan kualitasnya) (Hardjowigeno \& Widiatmaka, 2007), dan Danau Laimadat mempunyai ketersadiaan air yang memadai sepanjang tahun. Aktivitas perikanan yang ada pada saat penelitian dilakukan adalah kegiatan penangkapan ikan yang dilakukan oleh masyarakat setempat menggunakan alat tangkap tradisional. Belum terdapat kegiatan budidaya ikan yang dilakukan oleh mayarakat. Namun demikian, perairan Danau Laimadat sangat memungkinkan untuk dijadikan lokasi budidaya ikan air tawar.

Sumber air merupakan faktor utama dalam budidaya perikanan karena air merupakan media pertumbuhan ikan dan tempat pertumbuhan plankton yang merupakan salah satu sumber makanan ikan. Karena pentingnya sumber air bagi perairan danau, maka sumber air ini baik debit maupun kualitasnya dapat dijadikan sebagai ukuran penentuan daya dukung lingkungan perairan untuk budidaya. Sumber air sangat sensitif terhadap pembangunan/pengembangan kawasan perairan. Kuantitas air di perairan danau untuk kegiatan budidaya perikanan sangat dipengaruhi oleh parameter fisika dan kimia air danau. Kuantitas air sangat membantu dalam proses asimilasi limbah yang masuk ke danau yang berasal dari sekitar danau. Potensi sumber utama limbah di Danau Laimadat berasal dari pemukiman penduduk yaitu dari perkampungan masyarakat Radak Desa Malinjak. Limbah domestik tersebut jika tidak dikontrol akan berpotensi menurunkan oksigen terlarut (Muthifah et al., 2018). Oleh karena itu, perlu upaya yang berkelanjutkan untuk memahamkan masyarakat pentingnya menjaga perairan
Danau Laimadat agar tidak tercemar. Namun demikian, pada saat penelitian dilakukan secara visual tidak ditemukan polutan yang masuk ke perairan Danau Laimadat.

Dalam upaya pengembangan dan pelestarian fungsi lingkungan perairan (pengelolaan) akan selalu ada kegiatankegiatan seperti kegiatan pemanfaatan (termasuk penataan dan pemeliharaan), pengendalian, pemulihan dan juga penambangan kawasan lingkungan. Pembangunan berkelanjutan adalah upaya pelestarian yang paling baik, karena dalam prosesnya akan selalu memperhatikan daya dukung lingkungan perairan Danau Laimadat sehingga dapat dijadikan modal pembangunan untuk generasi-generasi selanjutnya. Ke depan, diharapkan perarian Danau Laimadat dan perairan umum lainnya di Indonesia tidak terabaikan pengembangannya. Menurut Kartamihardja et al. (2009) perikanan perairan umum daratan Indonesia terabaikan, baik tentang peranan kepentingan, penempatan prioritas dalam pembangunan, anggapan sebagai tempat pembuangan limbah, maupun informasi tentang potensi. Hasil penelitian Kartamihardja et al. (2009) diharapkan tidak terjadi lagi di masa yang akan datang, dan pengembangan peerikanan perairan umum dapat sepadan dengan perikanan laut.

Untuk mencapai hal tersebut, sebelum melakukan pengelolaan hendaknya ditentukan terlebih dahulu nilai dari daya dukung lingkungan perairan. Dalam penentuan daya dukung suatu kawasan perlu diperhatikan setidaknya tiga aspek utama, yaitu: ekologi, ekonomi, dan sosial. Hal ini penting mengingat interaksi antara kegiatan pengelolaan dengan ekosistem dari kawasan Danau Laimadat akan tergambarkan dengan sangat kompleks, sehingga memerlukan pendekatan yang multidimensi. Dengan keterpaduan antar multidimensi, diharapkan pemanfaatan Danau Laimadat 
dapat sinergis dalam beberapa peruntukan kegiatan.

\section{SIMPULAN}

Kualitas air ( $\mathrm{pH}$, suhu, dan oksigen terlarut) di Danau Laimadat sesuai dengan Standar Baku Mutu Perairan untuk budidaya ikan air tawar. Kedalaman perairan dan kecerahannya juga sesuai dengan persyaratan budidaya ikan air tawar yang optimum. Secara visual tidak ditemukan polutan dan indikasi pencemaran. Kondisi tersebut sangat mendukung pengembangan budidaya ikan air tawar di Danau Laimadat untuk meningkatkan pendapatan masyarakat di sekitar danau.

\section{DAFTAR PUSTAKA}

Andria, A. F., \& Rahmaningsih, S. (2018). Kajian Teknis Faktor Abiotik pada Embung Bekas Galian Tanah Liat PT. Semen Indonesia Tbk. untuk Pemanfaatan Budidaya Ikan dengan Teknologi KJA. Jurnal Ilmiah Perikanan Dan Kelautan, 10 (2), 95-105.

https://doi.org/10.20473/jipk.v10i2. 9825

Dahuri, R. (2003). Paradigma Baru Pembangunan Indonesia Berbasis Kelautan. Makalah Orasi Ilmiah. Sidang Pengukuhan Guru Besar Tetap Bidang Pengelolaan Sumberdaya Pesisir dan Lautan di Fakultas Perikanan dan Ilmu Kelautan, Institut Pertanian Bogor. Bogor: Institut Pertanian Bogor.

Hardjowigeno, S. \& Widiatmaka. (2007). Evaluasi Kesesuaian Lahan \& Perencanaan Tata Guna Lahan. Yogyakarta: Gadjah Mada University Press.

Investor Daily. (2014). Perikanan perairan umum Indonesia jadi andalan ketahanan pangan dunia. https://www.beritasatu.com/fabiolafebrinastri/nasional/206831/perika nan-perairan-umum-indonesiajadi-andalan-ketahanan-pangandunia. 20 Agustus 2020.

Kartamihardja, E.S., Purnomo, K., \& Umar, C. (2009). Sumber daya ikan perairan umum daratan di Indonesia-Terabaikan. Jurnal Kebijakan Perikanan Indonesia, 1 (1), 1-15.

Lihawa, F., \& Mahmud, M. (2017). Evaluasi karakteristik kualitas air Danau Limboto. Jurnal Pengelolaan Sumberdaya Alam dan Lingkungan, 7 (3), 260-266.

Muthifah, L., Nurhayati, \& Utomo, K.P. (2018). Analisis kualitas air Danau Kandung Suli Kecamatan Jongkong, Kabupaten Kapuas Hulu. Jurnal Teknologi Lingkungan Lahan Basah, 6 (1), 21-30.

Nybakken, J.W. (1988). Marine biology: an ecological approach. Harper collins publishers. New York. Terjemahan Eidman H.M. (1988). Biologi Laut: suatu pendekatan ekologis. Penerbit Gramedia, Jakarta.

Ningsih, F., Rahman, M., \& Rahman, A. (2016). Analisis Kesesuaian Kualitas Air Kolam Berdasarkan Parameter pH, DO, Amoniak, Karbondioksida, dan Alkanlinitas di Balai Benih dan Induk Ikan Air Tawar (BBI_IAT) Kecamatan Karang Intan Kabupaten Banjar. Fish Scientiae, 4(6), 102-113. https://doi.org/10.20527/fs.v3i6.114 1

Panggabean, T. K., Sasanti, A. D., \& Yulisman. (2016). Kualitas air, kelangsunga hidup, pertumbuhan, dan efisiensi pakan ikan nila yang diberi pupuk hayati cair pada air media pemeliharaan. Jurnal Akuakultur Rawa Indonesia, 4 (1), 67-79.

https://doi.org/10.1103/PhysRevE.4 9.126

Peraturan Pemerintah Republik Indonesia Nomor 82 Tahun 2001 Pengelolaan 
Kualitas Air dan Pengendalian Pencemaran Air. 14 Desember 2001. Lembar Negara Republik Indonesia Tahun 2001 Nomor 153. Jakarta.

Pulford, E., Polidoro, B., \& Nation, M. (2017). Understanding, the relationships between water quality, recreational, fishing practices, and human health in Phoenix, Arizona. Journal of Environmental Management, 199, 242-250.

[BSN] Badan Standardisasi Nasional. (2008). SNI 6989-57-2008 Metode Pengambilan Contoh Air Permukaan. Jakarta: Badan Standardisasi Nasional.

Undang-Undang Nomor 45 Tahun 2009 Perubahan Atas Undang-Undang Nomor 31 Tahun 2004 tentang Perikanan. 29 Oktober 2009.
Lembar Negara Republik Indonesia Tahun 2009 Nomor 154. Jakarta.

Yunita, R.A.N. \& Rachman, F. (2016). Cluster potensi sektor perikanan pada perairan umum di Jawa Timur tahun 2016. In Prosiding Seminar Nasional Pendidikan, Sains dan Teknologi (pp. 224-233). Semarang, Indonesia: Fakultas Matematika dan Ilmu Pengetahuan Alam, Universitas Muhammadiyah Semarang.

Zamzami, Z. N., Astriyani, R. N., \& Suharianto. (2019). Analisis Kesesuaian Kualitas Air Sungai dengan Baku Mutu Air untuk Budidaya Ikan Air Tawar di Kabupaten Tabalong. SPECTA Journal of Technology, 3 (3), 36-43. https://doi.org/10.35718/specta.v3i3 .131 